\title{
THE ANALYSIS OF THE CONNECTION OF TWO TOOLS OF A MODULAR DEVICE FOR SOIL APPLICATION OF THE DIGESTATE
}

\author{
Jacek WOJCIECHOWSKI, Zbyszek ZBYTEK, Tadeusz PAWLOWSKI, \\ Jarosław MAC, Florian ADAMCZYK \\ Przemysłowy Instytut Maszyn Rolniczych/ Industrial Institute of Agricultural Engineering, POLAND \\ e-mail of corresponding author: jacekw@ @imr.poznan.pl
}

Keywords: sustainable agriculture, digestate, modular device, connection of tools, forces

\begin{abstract}
The issue of connecting two collaborating tools in the scope of determination of forces occurring in the hitch of the tools was discussed. The analysis was carried out at the example of a modular device for soil application of digestate. In one working pass the device enables to organize a work enabling evenly spreading the digestate at the soil surface, mixing it and covering with soil. Finite Element Method (FEM) numerical methods have been used for the development of a construction which allowed, among others, the determination of loads at the point of the tools connection. Carrying out experimental research in real conditions of operation, stress distribution and force values occurring in connection were determined. The force values obtained were verified with computer analysis carried out at the 3D model of the device, demonstrating the correctness of the assumptions made.
\end{abstract}

\section{INTRODUCTION}

Care for soil environment and in particular the content of humus in soil is one of the assumptions of sustainable agriculture. The increase of humus in the soil may be obtained, among others, by means of the use of natural fertilizers, including, among others, digestate. In order to enable this process while meet the requirements for the use of natural fertilizers, a modular device for subsurface injection of digestate was elaborated. The principles of ecodesigning, ergonomics and work organization in sustainable agriculture were implemented when elaborating the construction of the modular device (Bohdal et al., 2014; Kukiełka et al., 2016). The set consists of a manure spreader and a trailed disc harrow. The device offers the possibility of work organization enabling the simultaneous transport, spreading and mixing of digestate with soil. A bracket with a transport hitch developed according to the principles of ergonomics, mounted to the spreader frame, was used to connect both machines. This type of attachment ensures the transfer of loads generated by the aggregated disc harrow. The disc harrow is equipped with a drawbar ended with an eye. High strength requirements are set for connections of such kind, subject to variable and different operational loads. In order to define the level of loads at the point of connection, Finite Element Method (FEM) numerical methods were applied (Savaidis and Vormwald 2000; Maggi et al., 2005; Rakowski and Kacprzyk 2005; Wang 2012; Kosterski et al., 2016). They are commonly applied in the Industrial Institute of Agricultural Engineering, in the scope of elaboration of the construction of agricultural machines working with variable operating loads (Szczepaniak and Pawłowski 2005; Zbytek et al., 2013; Kukiełka et al., 2016). Moreover, computer simulations which enable to verify the adopted constructional solutions of agricultural machines are performed (Szczepaniak and Pawłowski 2005; Zbytek et al., 2009; Pawłowski et al., 2012; Wojciechowski 2013). Verification of obtained parameters takes place in real conditions, during the operation of the machine. Various kinds of test runs are considered in the regard. The results obtained are verified with results obtained in the simulation test. 


\section{GOAL, OBJECT AND METHODS OF THE STUDY}

The analysis of the connection of two tools of a modular device for soil application of digestate, in the scope of identification of forces occurring in that connection, under conditions of variable operational load, was the one of the main objectives of the conducted research. Managing a digestate as per the R10 recovery process, it should be spread evenly at the field surface, covered and mixed with soil. In order to meet that condition, a modular device for soil application of digestate, which was the subject of tests, was designed (Fig. 1). The device construction computational model was performed with the use of the Ideas NX 6.3 system.

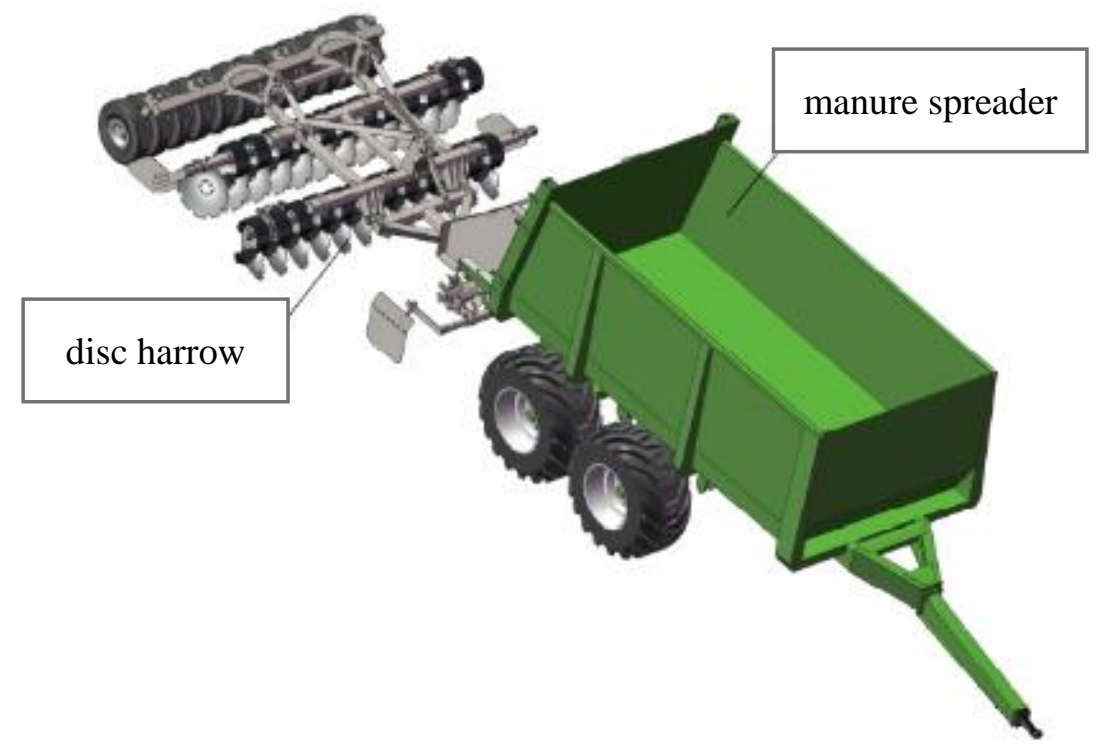

Fig. 1. Modular device for soil application of digestate

FEM mesh was built using standard finite elements located in the programme library. The computational model was discretizationed with quadrilateral and triangular shell and plate elements and beam elements. A computer analysis was carried out for the purpose of determination of the value of forces at the point of tools connection. Carrying out experimental tests under operational conditions, values of forces occurring in the place of connection of both machines were determined (Fig. 2). Strain gauge sensors stuck to a beam with the drawbar eye of the disc harrow were used to determine forces. Strain gauges were stuck in places located with the use of a strength analysis performed in the static scope. In order to determine forces loading the machine in the point of connection, a method discussed by Spadło (2014) was applied. With the method, a classical manner of determination of force values, by means of performance of normal stress equation calculations was resigned from. Geometric parameters and cross-section characteristics are replaced with constants which were then determined experimentally. Constants binding the stresses recorded in the drawbar with forces occurring in the hitch were identified on the basis of an experiment consisting in loading the drawbar in a location of occurrence of forces with significant value and readout corresponding to the stress. The direction of the load operation was selected so as to eliminate the remaining components. 


\section{RESULTS}

Registration of time course of force values in the disc harrow hitch was performed during the transport pass at a field road and two working pass. An exemplary course of forces occurring in the harrow's hitch during a transport pass at the field road is presented at Figure 3. Five measurement sections are designated at the force distribution: 1 - lifting of the disc harrow to the transport position 2 - ride down from the elevation, 3 - ride with a field road, 4 - ride up the elevation, 5 - stopping the tractor unit.

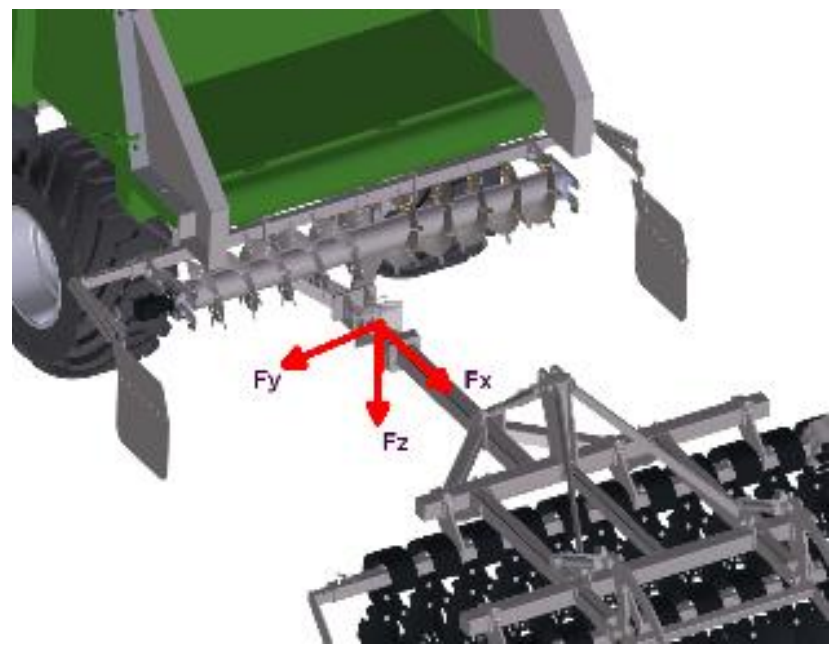

Fig. 2. Designation of forces occurring in the disc harrow hitch

Recorded values of forces during measurements are set in table 1. Negative values of forces mean another reversal of forces operation with respect to the one adopted at Fig. 2. Longitudinal force $F_{x}$, occurring at the point of connection, is the force of working resistance of the disc harrow during working pass. It was determined when spreading digestate with modular device, going at a working speed of $5 \mathrm{~km} \cdot \mathrm{h}^{-1}$ and mixing it with soil at a depth of $10 \mathrm{~cm}$.

Table 1. Values of forces occurring in the hitch during various runs.

\begin{tabular}{|c|c|c|c|c|c|}
\hline \multirow{2}{*}{ Item } & \multirow{2}{*}{ Tests } & \multirow{2}{*}{ Forces } & \multicolumn{3}{|c|}{ Values of forces [daN] } \\
\hline & & & $\min$. & $\max$ & average \\
\hline \multirow{3}{*}{1} & \multirow{3}{*}{ Transport pass } & longitudinal Fx & -267 & 780 & 79 \\
\hline & & lateral Fy & -201 & 65 & -2 \\
\hline & & vertical Fz & 0 & 807 & 606 \\
\hline \multirow{3}{*}{2} & \multirow{3}{*}{ First working pass } & longitudinal Fx & 1023 & 2082 & 1456 \\
\hline & & lateral Fy & -402 & -144 & -263 \\
\hline & & vertical Fz & 115 & 394 & 242 \\
\hline \multirow{3}{*}{3} & \multirow{3}{*}{$\begin{array}{l}\text { Second working } \\
\text { pass }\end{array}$} & longitudinal Fx & 1285 & 2298 & 1820 \\
\hline & & lateral Fy & -488 & -181 & -323 \\
\hline & & vertical Fz & 93 & 367 & 249 \\
\hline
\end{tabular}

The connection of two tools meets the requirements in the scope of the transfer of vertical force (PN-82/R-36107). The hitch transfer loads applied along its longitudinal axis max. $1820 \mathrm{daN}$, which is the force of working resistance of the disc harrow. The average value of working resistance $1638 \mathrm{daN}$ obtained, recorded during experimental tests, corresponds to the value of the force which was applied to the eye of the disc harrow's 
hitch during computer analyses at the 3D computational model. Working resistance adopted or the analysis at the computational model amounted to 1700 daN. Upon consideration in the computational model of the dynamic force coming from the tools' weight and their working resistance (dynamic surplus ratio $\mathrm{k}_{\mathrm{d}}=1.6$ was applied in the calculations), the value of reaction in the drawbar eye increased to the level of $2140 \mathrm{daN}$. Maximum value of the working resistance recorded during experimental tests, which amounts to 2190 daN, confirms the correctness of assumptions made and the method of carrying out computer analyses.
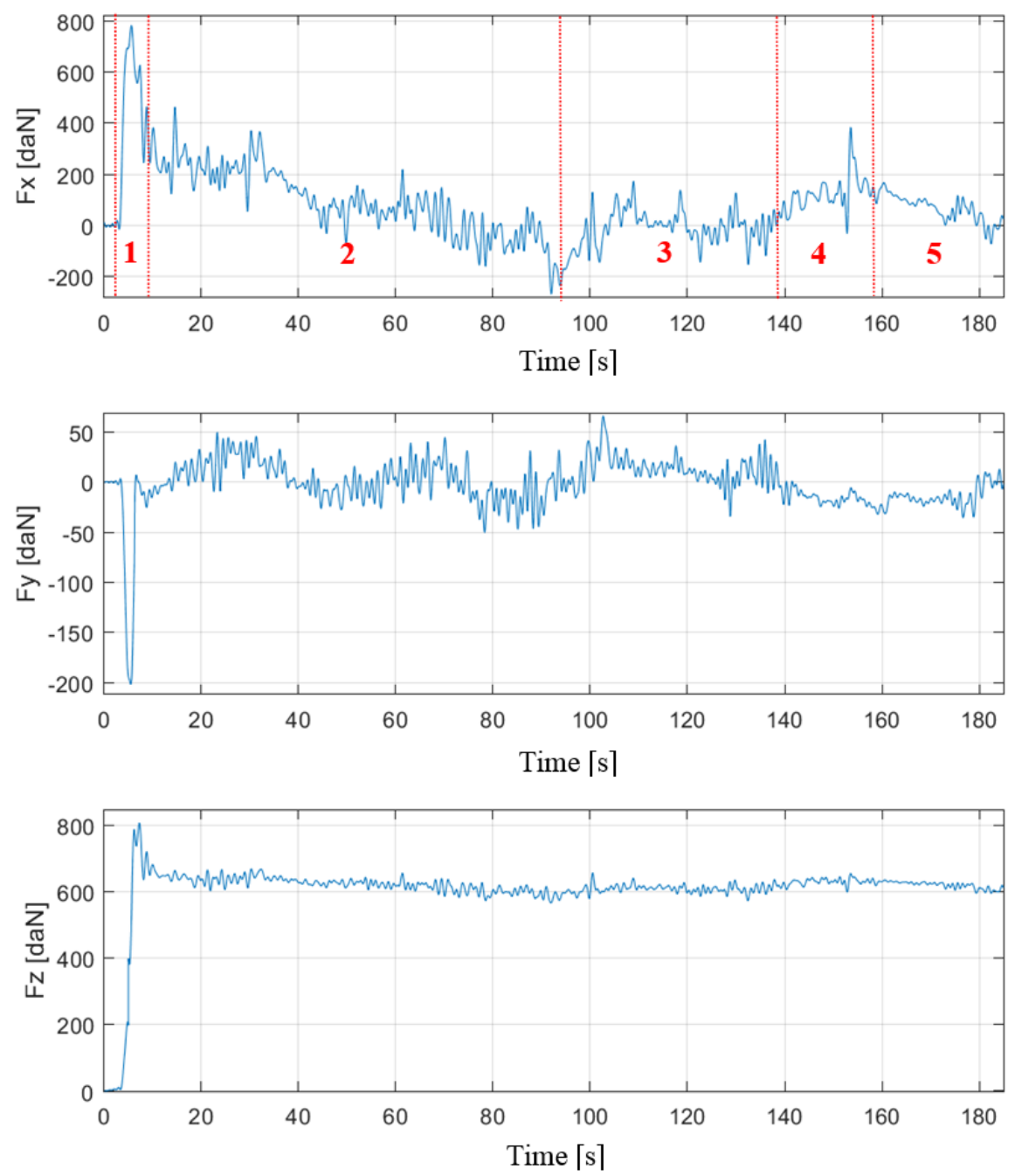

Fig. 3. Exemplary course of forces occurring in the hitch during the transport pass

\section{CONCLUSION}

The strain gauge method of values forces determination occurring in the point of connection of two collaborating agricultural machines was presented. The analysis was carried out at the example of a modular device for soil application of digestate. The device consisting of the manure spreader and trailed disc harrow, in one working pass, evenly spreads digestate at the soil area and mixes it and covers it with soil. The construction of the aggregate enables the reduction of energy expenditure as a result of the combination of two treatments in one pass which is in accordance with the principles of work 
organization in sustainable agriculture. FEM numerical methods have been used for the build of a 3D model of the modular device and determination of the level of forces at the point of the tools connection. The precision of numerical analyses carried out was verified experimentally with the use of strain gauge techniques. Experimental tests carried out in real conditions of operation allowed for determination of the value of forces occurring in connection during various runs. The course of force obtained allowed to determine average values. The hitch used for the connection of two tools meets the requirements in the scope of the transfer of vertical force. The validation of 3D model of the connection of collaborating tools proved the correctness of the assumptions made.

\section{ACKNOWLEDGMENT}

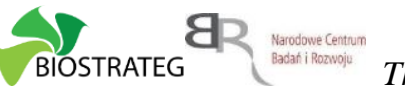
research and development program"En by the National Center for Research and Development BIOSTRATEG 1/269056/NCBR/2015. "Interdisciplinary research into improving energy efficiency and increasing the share of renewable energy sources in the energy balance of Polish agriculture".

\section{REFERENCES}

Bohdal Ł., Kułakowska A., Patyk R. (2014). Analysis of Slitting of Aluminum Body Panels in the Aspect of Scrap Reduction. Annual Set The Environment Protection, Volume 16, Year 2014, p. 105-114.

Kosterski N., Packer J.A., Puthli R.S. (2003). A finite element method based yield load determination procedure for hollow structural section connections. Journal of Constructional Steel Research, Vol 59, Issue 4, pages 453-471.

Kukiełka L., Kukiełka K., Kułakowska A., Zbytek Z., Lubiński A., Lubiński J. (2016). Innowacyjne rozwiązania w aspekcie ochrony środowiska w nowej generacji zaprawiarki porcjowej do ziaren zbóż. Annual Set The Environment Protection, Volume 18, Year 2016, pages 445-465.

Łowiński Ł., Zbytek Z. (2010). Load analysis of the agricultural machine’s carrying frame during work and transport runs. Journal of Research and Applications in Agricultural Engineering, vol. $55 \mathrm{nr}$ 1, pages 6367.

Maggi Y.I., Goncalves R.M., Leon R.T., Ribeiro L.F.L. (2005). Parametric analysis of steel bolted end plate connections using finite element modeling. Journal of Constructional Steel Research, Vol. 61, Issue 5, pages 689-708.

Pawłowski T., Wojciechowski J., Osmólski W. (2012). Movement dynamics of agricultural unit moving on public roads. Journal of Research and Applications in Agricultural Engineering, Vol. 57(2), pages 138144.

PN-82/R-36107 Ciągniki rolnicze. Zaczep rolniczy. Główne wymiary, wymagania i usytuowanie.

Rakowski G., Kacprzyk Z. (2005). Finite element method in structural mechanics. PW Publishing House, Warsaw.

Savaidis G., Vormwald M. (2000). Hot-spot stress evaluation of fatigue in welded structural connections supported by finite element analysis. International Journal of Fatigue, Vol. 22, Issue 2, pages 85-91.

Spadło M. (2014). Adaptacja metod analizy zmęczeniowej w aspekcie stochastyki obciążeń dla maszyn rolniczych. Rozprawa doktorska. Poznań.

Szczepaniak J., Pawłowski T. (2005). Modelowanie komputerowe I badania symulacyjne modeli maszyn rolniczych na przykładzie wału wahadłowego. Inżynieria Rolnicza, 7/2005, pages 313-321.

Wang Li-rui. (2012). Simulation and Improvement of Vehicle Frame Using FEM. Proceedings of the 2012 International Conference on Mechanical Engineering and Material Science (MEMS 2012). Published by Atlantis Press., pages 627-629. 
Wojciechowski J. (2013). Dynamics of impact of agricultural machinery on the tractors in the process of transport. Journal of Research and Applications in Agricultural Engineering”, Vol. 58(1), pages 193-198.

Zbytek Z., Spychała W., Adamczyk F., Łowiński Ł., Talarczyk W. (2009). Badania symulacyjne wpływu położenia dyszla transportowego na obciążenia kół jezdnych na przykładzie maszyny do zbioru wierzby krzewiastej. Zeszyty Problemowe Postępów Nauk Rolniczych 543, pages 409-416.

Zbytek Z., Nawrocki P., Łowiński Ł., Talarczyk W., Chojnacki J. (2013). Modeling and empirical verification of universal carrying frames for agricultural machinery. Journal of Research and Applications in Agricultural Engineering, vol. 58(2), pages 197-200. 